\title{
Correlation between the Concepts of "Detention" and "Suspicion" in the Criminal Proceedings of Russia and Germany
}

\author{
Ludmila V. Maiorova* and Yana M. Ploshkina \\ Siberian Federal University \\ 79 Svobodny, Krasnoyarsk, 660041, Russia
}

Received 14.06.2018, received in revised form 19.06.2018, accepted 28.06.2018

The study deals with one of the measures of criminal procedural coercion-detention and its correlation with the concept of "suspicion". Russian law fails to sufficiently regulate the issue on an individual's legal status under actual detention prior to criminal proceedings institution.

Analysis of coercive measures is equally relevant both for Russia and for Germany.

The doctrine of suspicion and significance of this concept in terms of criminal procedural coercion measures application have a long standing history in the criminal procedure law of Germany, so their analysis made by this research is of great importance to the Russian law enforcers. The definition of the concept of initial suspicion, the moment it occurs, as well as the way every specific occasion states the initial suspicion availability are of particular interest.

The increase in coercive measures as a response to modern challenges: the fight against terrorism and organized crime is accompanied by increasing sensitivity to more precise regulation of existing ones, and it certainly concerns the concept of detention in the Russian criminal process.

Keywords: detention, correlation with the concept of "suspicion", individual's legal status under actual detention prior to criminal proceedings institution, doctrine of suspicion, initial suspicion.

DOI: 10.17516/1997-1370-0294.

Research area: law.

The multidimensional nature of the understanding of the legal nature of procedural coercion and the need for its research is based on the content of possible and necessary coercive impact in the course of criminal proceedings. At present, the society sensitivity to more precise regulation is growing. The current model perceives as coercion those things which were not previously perceived as a violation of rights. At times it is not the new measures of coercion that appear but awareness of the need to refer an already acting measure to coercive ones.

Some authors point out that the Basic Law of the Federal Republic of Germany (Articles 13, 104) defines the conditions of procedural coercion application to an individual in more detail than the Constitution of the Russian Federation does. The condition to limit the rights of an individual is compliance with the requirements of the official law and its established procedure in particular ${ }^{1}$.

(C) Siberian Federal University. All rights reserved

* Corresponding author E-mail address: LVmaiorova@mail.ru 
There are more than 30 types of coercive measures in Germany and they are divided according to the legal benefits they are bound to limit. German legislation mainly provides coercive measures that affect freedom of movement (more than 10), freedom to dispose of property (about 5), information selfdetermination, etc. The Criminal Procedure Code of the Federal Republic of Germany (hereinafter FRG CPC) does not provide for the classification of measures of procedural coercion: they are contained in various sections and are jointly considered in legal literature as pursuing common goals and tasks.

\section{On the detention of a suspect}

One of the measures of criminal procedural coercion is the detention of a suspect. In the Russian criminal process, the determination of the discretion of law enforcement agencies, the exclusion of arbitrariness in their actions is relevant for the institution of detention, especially given the unsettled legal status of an individual in actual detention prior to the institution of criminal proceedings. The Constitution of the Russian Federation does not contain the concept of "detention of a suspect". However, Part 2 of Art. 22 of the Constitution of the Russian Federation stipulates that "an individual cannot be detained for more than 48 hours before a court decision passed".

It makes sense to analyze this constitutional legal norm: whether it means that the concept of "an individual" always equals a suspect or can turn into a suspect. Art. 92 of the Criminal Procedure Code provides that a suspect is brought to the body of inquiry or to the investigator. Logically, the question arises who has identified a delivered individual as a suspect. The wording of the article needs to be adjusted, since it contradicts the principle of the presumption of innocence contained in Art. 49 of the RF Constitution. An individual who has nothing to do with a crime, in a number of occasions may be forcibly brought to the investigator or to the body of inquiry. In the given situation, proceeding from the legal relationships that arise between law enforcement agencies and an individual forcibly brought to them, one should speak about any other legal status of an individual rather than the suspect. The Criminal Procedure Code of the Russian Federation remains unregulated the legal status of a person detained at a crime scene or after a crime commission, when a decision to initiate criminal proceedings has not yet been taken.

In practice it results in detaining individuals suspected in committing a crime in an agency of inquiry often on false grounds prior to a detention protocol provided by Art. 92 of the RF CPC 2 .

In some cases, when an individual is actually detained and brought to law enforcement bodies, it then becomes clear that the detention was unreasonable and unlawful (for example, the individual concerned had an alibi, eyewitnesses made a mistake, the victim defamed that individual etc.).

In our opinion, it would be more correct to consider that it is the detainee who is brought to law enforcement bodies (when this individual is captured, caught and then forcibly brought there). It is deemed that the term "detainee" can be introduced into the criminal procedure legislation. So, V.I. Rudnev believes that the detainee is an individual forcibly brought to the authorities in connection with his reasonably alleged involvement in the commission of a crime. The proposed definition of the term "detainee" will, perhaps, more closely correspond to the status of this individual and will distinguish it from the status of a suspect ${ }^{3}$.

The Russian legal literature draws attention to the non-regulation of the legal status of an individual being actually detained prior to the institution of a criminal case and notes that an 
imprecisely regulated legal regime for "actual detention" is used by some unscrupulous law enforcement officers to exert unlawful pressure on the detainee.

Detention of a suspect has both features common to all measures of criminal procedure coercion, and those which are characteristic only for this institution of criminal justice. A strict procedural form must guarantee the rights of an individual in the process of applying detention.

\section{On suspicion in criminal procedure of Russia and Germany}

The concept of "suspicion" is closely related to the concept of "detention". In order to apply measures of criminal procedure coercion, suspicion is necessary, since only when suspicion is established, interference by the criminal investigative authorities in constitutional human rights and freedoms is permissible 4 . Therefore, first of all, it is necessary to define the concept of "suspicion".

The Russian criminal procedure science has not devoted considerable attention to the doctrine of suspicion. Russian legal literature understands suspicion as the thesis of the criminal complicity of a certain individual in the commission of a crime, subject to verification and proof in the course of a preliminary investigation, which, in contrast to the affirmative thesis of the prosecution, is of a supposed nature and lesser degree of validity ${ }^{5}$.

The institution of suspicion is considered in the context of the institution of prosecution. The legal nature of suspicion lies in the fact that the investigator's opinion about the probable criminal complicity of a particular individual in the commission of a crime expressed in suspicion must be checked in order to justify the accusatory thesis ${ }^{6}$.

In the course of investigation, suspicion of an individual's criminal complicity in the commission of the crime may increase to such an extent that it will move to a new level - a charge. Suspicion as a thesis about the probable criminal complicity of an individual in a committed crime does not disappear, but develops into an accusative thesis based on evidence of the individual's criminal complicity and, consequently, reinforced by this evidence. Otherwise, if the thesis of criminal complicity (suspicion) is not confirmed, then an individual can acquire the procedural status of a witness or stops being a party to the criminal procedure altogether?. However, the Russian doctrine does not work out the issues: when, on what basis suspicion should be ascertained and when it grows into a charge.

Let us consider foreign experience that of Germany in particular, since the German criminal procedural doctrine and judicial practice pay considerable attention to the doctrine of suspicion. Suspicion runs through the entire German criminal process. Thus, when initial suspicion occurs it creates a material basis for a preliminary investigation, which takes the form of the inquiry ( $\$ 152 \mathrm{II}, 160 \mathrm{I}$ of the CPC of the Federal Republic of Germany) in the German criminal process. In this regard, some authors deem suspicion a central element of the entire German criminal process, since the presence of suspicion signifies the commencement of a criminal procedure investigation, and its absence obliges the prosecutor's office to immediately stop the initiated criminal investigation ( $\$ 170$ II of the CPC of the Federal Republic of Germany $)^{8}$.

In accordance with the predominant position of the FRG Supreme Court the science considers suspicion of a crime to be a strong-willed act of the body conducting the criminal prosecution, which expresses its position on the prosecution against the accused ${ }^{9}$.

However, the peculiarity of the German criminal procedure is that it is not acquainted with such procedural documents as the decision 
to initiate a criminal case and the decision to bring a person as an accused. It seems interesting how suspicion is established in Germany.

According to the German criminal procedural doctrine and a point of view prevailing in the FRG Supreme Court's practice, suspicion can be ascertained if there is a will of the body to prosecute the accused: when a formal criminal trial against the accused begins, when the person is interrogated as the accused, when the authorities, carrying out criminal prosecution, apply measures of procedural coercion to an individual or carry out measures, permissible only towards the accused, for example a short term detention ( $\$ 127$ II of the Criminal Procedure Code of Germany), custody ( $\$ 112$ of the Criminal Procedure Code of Germany), carrying out activities aimed at identification of an individual (taking blood samples, fingerprinting - $\S 81 \mathrm{a}$ and $81 \mathrm{~b}$ of the Criminal Procedure Code of Germany). Questions arisen in this connection are as follows: when suspicion of an individual and, consequently, acquisition of the procedural status of the accused should be ascertained and when coercive measures are possible to apply.

Judicial practice and the criminal procedural doctrine proceed from the fact that the criminal investigative body is obliged to declare the suspect the accused if the assumptions about an individual's complicity in the crime are reinforced to the objectively existing against him initial suspicion of committing an offense ${ }^{10}$.

In accordance with $\$ 152$ II of the German Criminal Procedure Code, the prosecutor's office is obliged to initiate a preliminary investigation when "sufficient evidence" is available. The theory and practice of the criminal process usually designates this point as the initial suspicion ${ }^{11}$.

According to $\$ 160$ I of the FRG Criminal Procedure Code, as soon as the prosecutor's office has learned from statements or by other means about suspicion of committing a criminal offense, it is obliged to investigate the circumstances of the case to resolve the issue of bringing a state charge.

Initial suspicion is a collection of certain factual data, which, taking into account forensic experience, allow us to conclude that an individual may be involved in a criminal act ${ }^{12}$. In order to ground initial suspicion, a sufficient set of certain factual data is needed to reflect possibility and likelihood of a crime commission by the given individual. Legal literature highlights that initial suspicion in order to justify interference in the rights of the accused, inevitable in the course of the preliminary investigation, should contain two points: the data on which suspicion is based must be, first, factual, and secondly, sufficient.

If only both points are available the data, which in themselves could hardly ground anything more than conjectures and assumptions, become initial suspicion. At the same time, data will be deemed factual if they are based on facts, that is, on specific events of the past directly related to a punishable act committed or not yet completed, and can be proved by available means; data can be considered sufficient if they reflect the possibility of committing a punishable $\mathrm{act}^{13}$. Assumptions based on the professional and life experience of the person conducting the criminal prosecution, without specific factual circumstances supporting the hypotheses, are not in themselves sufficient for ascertaining the initial suspicion ${ }^{14}$.

Nevertheless, one can not overlook the fact that assumptions, hypotheses as such do not appear from "nowhere"; they always have a certain basis, which entails their frequent transformation into initial suspicion in connection with the discovery of additional factual circumstances. When deciding on a sufficient set of factual data necessary to establish initial suspicion and, accordingly, to initiate a preliminary investigation, the prosecutor's office as a criminal prosecution body has a discretion, that is, a certain margin 
of appreciation, since suspicion, including initial one, is an appraisal concept. Any freedom of discretion ends where the arbitrariness of bodies conducting preliminary investigation begins, for example, those conducting certain investigative actions only on the basis of conjectures and assumptions ${ }^{15}$.

The German criminal procedure science and judicial practice have developed a design of a socalled "outside observer" which serves a tool to check whether initial suspicion is available or not. According to this design, the investigation should be based on such suspicion or a set of concrete facts that are sufficient from the point of view of any professional investigator, and this can be rechecked by replacing the results of a certain person's individual mental efforts with a third one in a comparable situation ${ }^{16}$.

Thus, suspicion plays a key role in the German criminal process, providing the basis for the initiation of a preliminary investigation to apply measures of criminal procedural coercion.

Not only the German criminal procedural doctrine, but also judicial practice, and the legislator are guided by the doctrine of suspicion in the course of the criminal proceedings. We believe it possible to use the experience of German criminal procedure law when developing the doctrine of suspicion, the moment suspicion occurs, as well as the concept of "detention of a suspect" in the Russian criminal procedural doctrine.

1 See: Ehngelgardt, A.A. (2008). Mery processualnogo prinuzhdeniya v ugolovnom processe frg [Measures of procedural coercion in the criminal process of the Federal Republic of Germany], In Mirovoj sudya [The world judge], 11, 12.

2 See: Chupilkin, Yu. (2008). Garantii prav lica zaderzhannogo do vozbuzhdeniya ugolovnogo dela [Guarantees of the rights of a person detained prior to the criminal proceedings institution], In Zakonnost [Legality], 12, 42-43.

3 See: Rudnev, V.I. (2017). Status zaderzhannogo kak novogo uchastnika ugolovnogo sudoproizvodstva [Status of the Detainee as a New Participant in Criminal Proceedings], In Zhurnal rossijskogo prava [Journal of Russian Law], 4, 15-17.

4 See: Bojlke, V. (2004). Ugolovno processualnoe pravo frg [Criminal Procedure Law of Germany]. Transl. from German Y. Ploshkinoj. Edited by L.V. Majorovoj. Krasnoyarsk, 183 p.

5 See: Dikarev, I.S. (2013), Podozrenie v ugolovnom processe [Suspicion in the criminal trial], In Zakonnost [Legality], 8, 20.

6 See: Petrov, I.V. (2012). Teoreticheskie I prakticheskie aspekty podozreniya v ugolovnom processe rossii [Theoretical and practical aspects of suspicion in the criminal process of Russia]. Krasnodar, $10 \mathrm{p}$.

See: Golovko, L.V. (2016). Kurs ugolovnogo processa [The course of the criminal process]. Moscow, Statut, $172 \mathrm{p}$.

See: Heger, M. (2013). Criminal procedural Law [Strafprozessrecht]. Stuttgart, 85 p.

9 See also: Bojlke, V. (2004). Ugolovno processualnoe pravo frg [Criminal Procedure Law of Germany]. Transl. from German Y. Ploshkinoj. Edited by L.V. Majorovoj. Krasnoyarsk, 79 p.

10 See also: Bojlke, V. (2004). Ugolovno processualnoe pravo frg [Criminal Procedure Law of Germany]. Transl. from German Y. Ploshkinoj. Edited by L.V. Majorovoj. Krasnoyarsk, 79 p.

11 See: Schroeder, F. C. (2014). Criminal procedural Law [Strafprozessrecht]. Muenchen, 43 p.

12 See also: Bojlke, V. (2004). Ugolovno processualnoe pravo frg [Criminal Procedure Law of Germany]. Transl. from German Y. Ploshkinoj. Edited by L.V. Majorovoj. Krasnoyarsk, 182 p.

13 See: Forkert-Hosser, S. (2011). Preliminary investigation in criminal procedure Law: Collection and use of data before the initial suspicion [Vorermittlung im Strafprozessrecht: Erhebung und Verwendung von Daten vor dem Anfangsverdacht]. Frankfurt am Main, $164 \mathrm{p}$.

14 See: Haas, G. (2003). Pre-investigations and initial suspicions [Vorermittlungen und Anfangsverdacht]. Berlin, 21 p.

15 See: Putzke, H., Scheinfeld, J. (2012). Criminal procedural Law [Strafprozessrecht]. Muenchen, 10 p.

16 See also: Forkert-Hosser, S. (2011). Preliminary investigation in criminal procedure Law: Collection and use of data before the initial suspicion [Vorermittlung im Strafprozessrecht: Erhebung und Verwendung von Daten vor dem Anfangsverdacht]. Frankfurt am Main, $56 \mathrm{p}$.

\section{References}

Bojlke, V. (2004). Ugolovno processualnoe pravo frg [Criminal Procedure Law of Germany]. Transl. from German Y. Ploshkinoj. Edited by L.V. Majorovoj. Krasnoyarsk, 325 p.

Chupilkin, Yu. (2008). Garantii prav lica zaderzhannogo do vozbuzhdeniya ugolovnogo dela [Guarantees of the rights of a person detained prior to the criminal proceedings institution], In Zakonnost [Legality], 12, 42-43. 
Dikarev, I.S. (2013). Podozrenie $\mathrm{v}$ ugolovnom processe [Suspicion in the criminal trial], In Zakonnost [Legality], 8, 20.

Ehngelgardt, A.A. (2008). Mery processualnogo prinuzhdeniya v ugolovnom processe frg [Measures of procedural coercion in the criminal process of the Federal Republic of Germany], In Mirovoj sudya [The world judge], 11, 12.

Forkert-Hosser, S. (2011). Preliminary investigation in criminal procedure Law: Collection and use of data before the initial suspicion [Vorermittlung im Strafprozessrecht: Erhebung und Verwendung von Daten vor dem Anfangsverdacht]. Frankfurt am Main, 399 p.

Golovko, L.V. (2016). Kurs ugolovnogo processa [The course of the criminal process]. Moscow, Statut, $1278 \mathrm{p}$.

Haas, G. (2003). Pre-investigations and initial suspicions [Vorermittlungen und Anfangsverdacht]. Berlin, $109 \mathrm{p}$.

Heger, M. (2013). Criminal procedural Law [Strafprozessrecht]. Stuttgart, 188 p.

Petrov, I.V. (2012). Teoreticheskie I prakticheskie aspekty podozreniya v ugolovnom processe rossii [Theoretical and practical aspects of suspicion in the criminal process of Russia]. Krasnodar, $22 \mathrm{p}$.

Putzke, H., Scheinfeld, J. (2012). Criminal procedural Law [Strafprozessrecht]. Muenchen, $213 \mathrm{p}$.

Rudnev, V.I. (2017). Status zaderzhannogo kak novogo uchastnika ugolovnogo sudoproizvodstva [Status of the Detainee as a New Participant in Criminal Proceedings], In Zhurnal rossijskogo prava [Journal of Russian Law], 4, 15-17.

Schroeder, F.C. (2014). Criminal procedural Law [Strafprozessrecht]. Muenchen, 298 p.

\title{
Соотношение понятий «задержание» и «подозрение» в уголовном процессе России и Германии
}

\author{
Л.В. Майорова, Я.М. Плошкина \\ Сибирский федеральный университет \\ Россия, 660041, Красноярск, пр. Свободныий, 79
}

Статья посвящена одной из мер уголовно-процессуального принужсения - задержанию и его соотношению с понятием «подозрение». В российском праве недостаточно урегулирован вопрос о правовом положении лица при фактическом задержании до возбуждения уголовного дела.

Анализ мер принуждения одинаково актуален как для России, так и для Германии.

В уголовно-прочессуальном праве Германии учение о подозрении и значение данного понятия для применения мер уголовно-процессуального принуждения имеют исторически длительный период, поэтому их анализ в статье имеет значение для российского правоприменителя. Особый интерес представляет определение понятия начального подозрения, момент его возникновения, а также каким образом в каждом конкретном случае констатируется наличие начального подозрения.

Увеличение мер принуждения как ответ современным вызовам: борьбе с терроризмом и организованной преступностью, сопровождается возрастающей чувствительностью к более 
точной регламентации уже существующих, что, безусловно, касается понятия задержания в российском уголовном процессе.

Ключевые слова: задержание, соотношение с понятием «подозрение», правовой статус фактически задержанного лица до возбуждения уголовного дела, учение о подозрении, начальное подозрение.

Научная специальность: 12.00.00-юридические науки. 
